Др Зорица ВУКАШИНОВИЋ РАДОЈИЧИТ *

Криминалистичко-полицијска академија, Београд

doi:10.5937/bezbednost $1702027 \mathrm{~V}$

UDK: 3.08(497.11):331.101.262

Originalni naučni rad

Primljen: 14. 9. 2017. godine Datum prihvatanja: 26. 10. 2017. godine

\title{
Development of Administrative Capacities through development of the Competency Framework ${ }^{* *}$
}

Abstract: In the context of the public administration reform in the Republic of Serbia, the accent is on the development of professional capacities and introduction of civil servants' competencies. The aim of the paper is to point out to the overall context of the public administration reform in the Republic of Serbia and the latest reform trends regarding establishment of an integrated and competency-based civil service. The author emphasizes the importance of the integration of Competency framework in civil service legislation, which is in accordance with European Civil Service standards and the Human Resource Management Framework Policy for Public Administration in the Republic of Serbia. Pursuant to this paper, competencies add up to collection of knowledge, skills and behaviour required for effective performance of work tasks. The author concludes that in the context of introducing competencies in the civil service system of the Republic of Serbia, changes in legal framework are required - primarily in the Law on Civil Servants, and other laws

\footnotetext{
* др Зорица Вукашиновић Радојичић, ванредни професор, Криминалистичкополицијска академија, zorica.vr@kpa.edu.rs

** Рад је резултат реализовања научноистраживачког пројекта под називом $P a$ звој институционалних капаџитета, стандарда и процедура за супротстављање организованом криминалу и тероризму у условима међународних интеграција. Пројекат финансира Министарство науке и технолошког развоја Републике Србије (бр. 179045), а реализује Криминалистичко-полицијска академија у Београду (2011-2017). Рад је такође резултат рада на интерном пројекту Криминалистичко - полицијске академије под називом Криминалитет у Србији и инструменти државне реакичје (2015-2019).
} 
and bylaws. For a competency framework to be efficiently implemented, education of civil servants is required.

Key words: Administrative reform, professionalization, public interest, Competency based human resource management.

\section{Introduction}

Public administration is a dynamic whole, facing numerous challenges on a daily basis. Modern administration needs staff with developed knowledge, trained to use new working methods adapted to a different environment which it gradually becomes. Only a professional public administration that rests on the principle of merits (skills) and responsibilities of civil servants can effectively meet the requirements posed by the reform process. Therefore, the establishment of professional administration is the key for successful reform. The emphasis is on professional capacity development and introduction of civil servants' competencies. The favoured principle is the one of merit, which encourages the recruitment, allocation and advancement of individuals who have particular education/knowledge, skills, personal attributes, attitudes, work experience and fulfil other criteria required to successfully perform job duties. Public interest drives and gives meaning to everything civil servants do.

The main objective of the reform is to improve work of public administration and to ensure high quality of services provided to citizens and companies, and to create a public administration that would contribute to economic stability. One of the main objectives is to establish a harmonised civil service system based on merits and to improve human resource management. Only a professional meritbased public administration (competencies) and accountability of civil servants can successfully meet requirements brought on during reform process.

As the external and internal environments constantly change, so do the job-related tasks and knowledge and skills necessary for their effective performance. Knowledge acquired at university, in an academic setting, certain number of years back in the past, rapidly becomes obsolete, and what is required is continuous acquisition of new knowledge, in order to keep pace with the dynamics of the external environment and to accomplish the goals of administration. 
The concept of competencies makes it possible for an organisation to identify the potential of existing servants and reassign them to jobs where they can achieve the highest performance. It is often the case that individuals perform very effectively at their jobs, but demonstrate poor performance when transferred to other jobs. The reason is that the servants lack competencies required for the new role. A competence-based planning for civil servant career development should ensure that individuals perform to their maximum potential, which thus reinforces the effectiveness of the entire administration.

\section{The notion and relevance of the Competency framework}

The ideas about competency have emerged in the past two decades or so. Reflecting dissatisfaction with their capacity in various roles and concerns about effective leadership in public management competency is a central issue in the ideas of modern reforms. Trends such as globalization create a need for new capacities to exploit new opportunities and put greater demands to public servants. Besides, modern management and new approaches to leadership are required, which are better at inspiring professionalism, integrity and accountability in the civil service. Changing environment and changing expectations of public servants have ensured that developing top officials has become a major part of human resource efforts in many countries.

To improve the efficiency of administration and achieve its strategic goals, a large number of the EU countries have introduced competencies into their civil service systems. The first to do so were the UK and Sweden during the 1980s, followed gradually by countries of continental legal tradition, such as Austria and France (Nunes et al., 2007). The now long-standing practice of using competencies in HR management has, in many EU countries, has shown positive results, particularly in improving the quality of services provided to citizens (Beck, et al., 2010).

In addition, competencies provide a critical mechanism for integration of human resource practices which is considered essential to a strategic approach. More specifically, competency models unify and coordinate the elements of the Human Resource management System. Once a competency framework has been researched and 
designed it can be used in recruitment, selection, training and development, performance management and reward systems (Hondeghem, 2002; Horton, 2000). For the competency model to be effective, several standards need to be developed. It has been maintained that competency models have to be aligned with the organizational goals and objectives. Competency models are expected to be sufficiently comprehensive to identify the competencies that distinguish exemplary employee performance. The framework is used for recruitment, performance management, for decision about promotion and professional development.

Bearing in mind the relevance of the topic, and the fact that the concept of competencies is still little known among the professional community, this paper aims to clarify the meaning and importance of competencies in human resource management in public administration. It will also provide a brief overview of comparative legislations in the region and analyse and suggest means for introducing competencies in the public administration system of the Republic of Serbia.

Like many other tools in public administration, the system of competencies originates in the private sector. Model of competencies is tailored to company's organisational culture and its strategic goals, which means that companies set it as a long-term objective, but that it needs to be reviewed and adjusted over time. Although each model has its own distinct features and should be developed in line with a given company, some competencies or behaviours are common to most models as they represent behaviours that are desirable and affirmative for any business environment.

The pioneering work on competencies was done by the company McGee Consultants, founded by David McClelland and his associates in the 1960s. The company developed and tested a competency model in twenty-two countries, across a large number of organisations, including public administration organisations, such as the US Department of State. Today, almost all international corporations have a developed concept of competencies in all major areas of human resource management.

The original competency model developed by McBer included technical, managerial and behavioural competency requirements for achieving superior performance at work. Technical, or functional competencies refer to knowledge needed to carry out a specific task, 
including the possession of relevant licenses, permits, certificates or other evidence of professional competence, as well as skills (e.g. computer skills, operating specific types of vehicles, operating specific machinery, etc.). Managerial competencies include management and leadership skills. Behavioural competencies refer to behaviour patterns that an individual needs to exhibit in order to carry out job-related tasks effectively (e.g. communication, team work, integrity, etc.)

The work on competencies, however, yielded an interesting finding. Identifying and assessing technical and managerial competencies in an individual proved to be a relatively easy task. Much more difficult was to assess the possession of personal competencies, i.e. behavioural competencies. Another finding was that technical skills development is relatively easy and not time-consuming. Behavioural competencies, by contrast, are deeply rooted and not easy to develop. Some of them, such as good communication skills, are indeed deeply rooted and not easily developed. Hence, the competency focus shifted from technical and managerial to behavioural competencies. While the identification of organisational or individual work objectives set out what needs to be done, competencies set out how to work to achieve the set objectives. ${ }^{1}$ While basic (behavioural) competencies relate to ways civil servants behave, functional competencies relate to their knowledge and skills. It is highly pointed out that competencies should be connected with all elements of human resources management function, such as: human resources planning, job position analysis, recruitment and selection, allocation, mobility, evaluation and reward system, personal development and career development. They imply that a successful work in public administration does not depend only on "what we do", but also "how we perform tasks".

The notion of competency is defined differently across Europe. Competencies are generally taken to mean knowledge, skills and behaviours featured in individuals with best performance in an organisation. In the literature, competency is most commonly referred to as a set of knowledge, skills, personal characteristics and abilities of an individual, which shapes the behaviour of that individual and leads

\footnotetext{
${ }^{1}$ See: Civil Service Human Resources, Civil Service Competency Framework 20122017.
} 
to the expected performance at work. ${ }^{2}$ It is also defined as 'an individual ability that combines skills, attitudes and behaviours in response to the requirements of the particular role in a given context of societal evolution and organisational complexity. ${ }^{3}$

A competence in general can be understood as the ability of an individual to activate, use and connect the acquired knowledge in the complex, diverse and unpredictable situations. In addition to that, competencies as the ability to use knowledge and other capabilities, necessary for successful and efficient accomplishment of an appointed task, transaction of work, goal realization, or performance of a certain role in the business process (Gruban, 2003). Competencies encompass knowledge, expertise, skills, personal and behavioural characteristics, beliefs, motives, values (Pagon, et al., 2008).

Definitions of competency, however, vary from country to country, and include the following:

1) a set of knowledge, skills, abilities, motivation, beliefs, values, interests;

2) basic individual characteristics related to effective and superior performance in a job;

3) knowledge, skills, abilities and traits associated with outstanding performance on a job;

4) a combination of motives, traits, attitudes and values or cognitive behaviour abilities;

5) any individual trait that can be measured reliably and that can be shown to differentiate superior performance from average performance;

6) personal skills crucial for achieving work objectives;

7) behaviour of an individual who can be expected to positively or negatively contribute to organisational efficiency. ${ }^{4}$

\footnotetext{
${ }^{2}$ See: Human Resource Management Service of the Government of RS, Manual on determining competencies for effective job performance (Приручник за одређивање компетениија за делотворан рад на радном месту).

${ }^{3}$ See: H. Rato, C. Baptista, D. Ferraz, M. Rodrigues, MANFOP Guide - Training Needs Assessment in Public Organisations (Vodič za MANFOP - Procena potreba za obukom u javnim organizacijama), p.10.

${ }^{4}$ See: Competency Management in EU Public Administration, EUPAN - Human Resources Working Group, Survey commissioned by the Portuguese EU-Presidency, December, 2007.
} 
Recognising the importance of behavioural competencies, in the past few years most countries in the region have begun testing for the possession of a limited number of these competencies during the selection process, which apply to all candidates for civil servant positions. Thus, for example, in Montenegro, the written part of the selection procedure assesses, among other skills, the analytical approach, precise and clear expression, as well as stating ideas with clarity and logic, while communication skills are assessed through interview. ${ }^{5}$ In the Federation of Bosnia and Herzegovina, during the interview, the recruitment commission evaluates, among other abilities, the analytical skills, communication skills and the development potential of applicants. ${ }^{6}$ In Macedonia, the interview checks for general occupational competencies required for the category to which the job belongs, as well as job-specific competencies in accordance with the job description. ${ }^{7}$

Most countries in the region have developed competency frameworks that include behavioural competencies. These frameworks contain a broad spectrum of behavioural competencies for civil servants that differ for non-managerial and managerial posts (including some of the previously mentioned), like for example: professional development; problem solving; results achievement; communication; teamwork; employee management and development skills (for managerial positions). No mechanism, however, was developed for using competencies in various stages of the human resource management process, and particularly in the recruitment procedure. Job descriptions in the majority of countries included in the analysis specify technical competencies (necessary professional knowledge), with behavioural competencies, however, still not finding their way in. That is why specific technical (professional) knowledge has been

${ }^{5}$ See: Article 13 and Article 15 determining the procedure for mandatory competency checks, specific criteria and methods for assessing candidates for posts in a public authority, 'Official Journal of Montenegro', No 04/13 of 18.1.2013.

${ }^{6}$ Regulation on the conditions, manner and curriculum of the general exam and specialised exam for candidates for civil service in the Federation of Bosnia and Herzegovina (Uredba o uslovima, načinu i programu polaganja ispita općeg znanja $i$ stručnog ispita za kandidate za državnu službu u Federaciji BiH), "Official Gazette of FBiH" No. 67/06, 78/06, 63/08.

${ }^{7}$ See: Article 42 of the Administrative Servants Act.

БЕЗБЕДНОСТ 2/2017 
assessed much more often in the selection procedure than behavioural competencies.

The work on the introduction of competencies commences with the identification of knowledge, skills and behaviour patterns needed for the administration to achieve its goals, which are then systematised in the so-called 'competency frameworks'. Competencies are created from the analysis of intermediate and long-term objectives to be achieved by the administration, as an organisation, and the job description analysis. It is common practice to systematise them into the so-called 'competency framework', which features all identified competencies, generally structured into several clusters.

\section{Competency development process in Serbian Civil Service}

Starting from the European Union's guidelines on the needs of civil service development, the Republic of Serbia adopted strategic documents - the Public Administration Reform Strategy of the Republic of Serbia and the Action Plan for the Public Administration Reform Strategy for 2015-2017, the Strategy for Professional Development of Civil Servants in the Republic of Serbia, the Fiscal Strategy for 2017 with Projections for 2018 and 2019, the Strategy for Development of Internal Financial Control in Public Sector in the Republic of Serbia 2017-2020, etc. ${ }^{8}$ The importance of the Action Plan for Chapter 23 should also be noted. This document represents a strategic umbrella document in the field. It provides for the activities of adoption and implementation of a human resource strategy for the judiciary, based on analysis of needs and volume of work. ${ }^{9}$ The above

\footnotetext{
${ }^{8}$ See: The Public Administration Reform Strategy in the Republic of Serbia and the Action Plan for the Public Administration Reform Strategy, the Ministry of Public Administration and Local Self-Government, Belgrade, March 2005; the Public Administration Reform Strategy in the Republic of Serbia for 2014-2016 (Official Gazette of RS 020-656/2014), Belgrade, 2014; The Strategy for Professional Development of Civil Servants in the Republic of Serbia (Official Gazette of RS 56/2011, 51/2013); Government of RS, the Fiscal Strategy for 2017 with Projections for 2018 and 2019, 2017; the Strategy for Development of Internal Financial Control in Public Sector in the Republic of Serbia for 2017-2020, 2017.

9 See: the Republic of Serbia, Negotiation Group for Chapter 23, Action Plan for Chapter 23, 2015.
} 
mentioned acts make foundation for systemic approach to the public administration reform and define course of its development.

Establishment of an integrated and competency-based human resource management system was envisaged in the Human Resource Management Framework Policy for Public Administration in the Republic of Serbia. ${ }^{10}$ Pursuant to this document, competencies add up to a collection of knowledge, skills and behaviour required for effective performance of work tasks. While basic (behavioural) competencies relate to ways civil servants behave, functional competencies relate to their knowledge and skills. ${ }^{11}$

Based on the above mentioned reform tendencies, and strategic and regulatory framework, a value system was developed - work objectives of the public administration in the Republic of Serbia. This is the starting point for the elaboration of a competency framework. These values represent an ideal state that an individual, organisation and society should strive to achieve and that should guide their activities and behaviour. Key values in the state administration are derived from the main objective that implies the establishment and development of a functional and coherent public administration system where competent civil servants legally, professionally and responsibly perform jobs of public importance with orientation towards needs of citizens, private sector and other beneficiaries of public services.

It is important to point out that competencies should be connected with all elements of human resource management function, such as: human resource planning, job position analysis, recruitment and selection, allocation, mobility, evaluation and reward system, personal development and career development. They imply that a

10 See: The Ministry of Public Administration and Local Self-Government, the Human Resource Management Framework Policy for Public Administration in the Republic of Serbia, 2017.

11 The activities on the introduction of a competency system began in 2011 with the support from IPA. Currently underway is the project 'Support to Public Administration Reform' where one of the objectives is the development of a competency framework. Establishment of an integrated and competency-based human resource management system was envisaged in the Human Resource Management Framework Policy for Public Administration in the Republic of Serbia. 
successful work in public administration does not depend only on "what we do", but also on "how we perform tasks". In the context of introducing competencies in the civil service system of the Republic of Serbia, changes in legal framework are required - primarily in the Law on Civil Servants, and other laws and bylaws. For a competency framework to be efficiently implemented, education of civil servants is required.

The system of competencies will be further developed and introduced in the Serbian legal system through amendments to the Law on Civil Servants and the accompanying secondary legislation. During this process, it should be borne in mind that the level of details is a critical aspect in creating a competency model. If the model is too simplified (it includes, for example, only generic descriptions of behaviour) it will not be able to provide an answer to what is exactly expected of civil servants, and the managers will be challenged while monitoring and assessing the work. On the other hand, a too detailed model will lead to excessive complexity of the process, extensive red tape and time consumption that will affect the credibility of the process, resulting in resistance from both the civil servants and their managers.

Competences will constitute a common part of integrated human resource management process, and are going to be gradually introduced in the human resource planning. When planning the needs for new employees it will be necessary to observe not only their qualifications and the number of employees needed, but also the specific competencies required for every specific job post.

Selection process will require, in addition to testing of functional competencies for a given position, the assessment of behavioural competences needed for an individual post. After analysing the job description for a vacancy to be filled, competition commissions (selection panels) will choose competences from the competency framework which will be tested during the selection process. For non-managerial civil service posts, the competences will be selected from the competency framework for non-managerial jobs, while for senior managerial and middle management civil service posts, the competencies shall be picked from the competency framework for management positions. 
Special attention shall be paid to testing the competencies for senior managerial positions (senior civil servants and some middle management civil service posts), whereby the method of assessment centre method will be used, as it is considered to be the most reliable method for the competence testing. The competence testing for non managerial jobs will be primarily based on somewhat simpler, but also relevant competence assessment methods, such as the standardized psychometric tests and standardized competency based interviews. This implies clearly defined criteria for competency assessment, and training of members of competition commissions who must have knowledge on the manner of selecting competencies for certain jobs, manner of testing and manner of evaluation of certain competencies.

Performance appraisal system will be reshaped and will include evaluation of accomplished results and demonstrated competencies necessary for a specific job position. Instead of the current assessment criteria (both for non-managerial and managerial positions) which are the same for all positions and which include: independence, creativity, resourcefulness, accuracy, diligence and quality cooperation, civil servants will be assessed based on demonstrated competences for nonmanagerial positions from the competency framework, while senior civil servants and middle management occupants will be appraised based on the managerial competencies from the competency framework. The appraisal system will also be more focused on future needs for employees' competence development. This purports changes in the current evaluation criteria. Bylaws will in a greater detail prescribe competencies that should be checked for executive and nonexecutive jobs. The obligation of monitoring future needs for competency development also needs to be established. With a view of full implementation of the merit system, when advancing to a higher rank or transferring to another public administration authority, servants must have competencies required for performing tasks in a higher rank.

For defining values of public administration's work and establishing a competency framework, a detailed analysis of legal framework is required - of relevant laws and bylaws regulating work of public administration, status and work principles of civil servants. This is primarily the Law on Civil Servants, but other laws as well. A professional civil service requires alignment of legal employment status in state/public administration. At the same time, this influences 
coherent functioning of the administration and efficient performance of administrative jobs at the central and local levels.

Additionally, pursuant to this law, certain rights and duties of civil servants in particular state authorities may be regulated differently by a special law if the need should arise from the nature of their work. A special civil service system is typical for the police, military, foreign affairs, custom and tax authorities, the Administration for Enforcement of Criminal Sanctions, provincial authorities, organisations and services, and for authorities, organisations and services of local government units.

\section{Concluding remarks}

One of the main objectives of the public administration reform is to establish a harmonised civil service system based on merits and to improve human resource management. Only a professional meritbased public administration (competencies) and accountability of civil servants can successfully meet requirements brought on during the reform process.

Continued development of a professional and depoliticized civil service system is one of the key requirements for lawful, expert and effective performance of administrative jobs that exercise public functions and implement policy. The merit principle encouraging employment, allocation and advancement of persons having certain education/knowledge, abilities, personal traits, attitudes, work experience and other criteria required for successful discharge of work duties is favoured. A professional employee profile springs from main tasks and responsibilities of a job and provides details on qualifications, skills, experience and the most important competencies required for the successful performance of work tasks.

In the Serbian Civil Service, the activities on the introduction of a competency framework have been intensified. In accordance with the Draft of the Competency framework, competencies add up to a collection of knowledge, skills and behaviour required for the effective performance of work tasks. While basic (behavioural) competencies relate to the ways civil servants behave, functional competencies relate to their knowledge and skills. They imply that a successful work in public administration does not depend only on "what we do", but also on "how we perform tasks". Competencies should be connected with 
all elements of human resource management function, such as: human resource planning, job position analysis, recruitment and selection, allocation, mobility, evaluation and reward system, personal development and career development.

In the segment of human resource planning, selection and recruitment, candidates' competency assessment must have full implementation. This implies clearly defined criteria for competency assessment, and training of members of competition commissions who must have knowledge on the manner of selecting competencies for certain jobs, manner of testing and manner of evaluation of certain competencies. Additionally, it is particularly important that performance appraisal system is founded on an established competency framework. This purports changes in the current evaluation criteria. Furthermore, competences should be identified in a performance appraisal system and related to civil servants' professional training.

In the context of introducing competencies in the civil service system of the Republic of Serbia, changes in the legal framework are required - primarily in the Law on Civil Servants, and other laws and bylaws. Therefore, the legislation changes should involve all relevant provisions regarding key human resource management function planning, recruitment and selection, allocation, mobility, performance appraisal system, promotion and professional development.

For a competency framework to be efficiently implemented, education of civil servants is required. It is concluded that the biggest challenge is still ahead - successful implementation of the Competency framework in the Serbian civil service system.

\section{References}

1. Beck, S., Hondeghem, A., (2010). Competency Management in the Belgian Federal government.

2. Civil Service Human resources, Civil Service Competency Framework, (2012-2017).

3. Competency Management in EU Public Administration, EUPAN - Human Resources Working Group, (2007). Survey commissioned by the Portuguese EU-Presidency.

4. EU Commission Report Serbia, (2016). 
5. Европска комисија, (2015). Извештај о напретку за Републику Србију, који прати Саопштење Комисије упућено Европском парламенту, Савету, Европском економском и сочијалном комитету и Комитету региона.

6. Government of RS, (2017). The Fiscal Strategy for 2017 with Projections for 2018 and 2019.

7. Gruban, B. (2003). Kompetence: moda, kit raja cetiri desetletja. Finance, 168/1596.

8. Hondeghem, A. (2002). "The state of the Art in the Public Sector?" In S. Horton (Ed.) (2000) Competency Management in the Public Sector. IOS Press.

9. Human Resource Management Service of the Government of RS, Manual on determining competencies for effective job performance (Приручник за одређивање компетениија за делотворан рад на радном месту).

10. Канцеларија за европске интеграције Владе РС, (2014). Национални програм за усвајање правних тековина ЕУ, (National Programme for the Adoption of the Acquis-NPAA, зa период до 2018).

11. Miklic P, (2014). “Analiza upravljanja ljudskim potencijalima u državnoj službi u BiH”, Izveštaj pripremljen na projektu Modernisation of HRM in the Civil Service, finansiranim od strane EU.

12. Министарство државне управе и локалне самоуправе, (2017). Оквир политике управљања људским ресурсима у државној управи Републике Србије.

13. Nunes, F., Martins, L., Duarte, H. (2007). Competency Management in the Portuguese EU-Presidency-EUPAN Human Resource Working Group.

14. Pagon M., Banutai E., Bizjak U., (2008). Leadership Competencies for Successful Change Management, A preliminary Study Report, Slovenian Presidency of the EU.

15. Pant P.D., Dutta, A., The Management Group, Behavioural Competencies - an Important H Tool.

16. Rato, H., Baptista, C., Ferraz, D., Rodrigues, M., Vodič za MANFOP - Procena potreba za obukom u javnim organizacijama. 
17. Служба за управљање кадровима Владе РC, (2011). Приручник за одређивање компетенција за делотворан рад на радном месту.

18. The Ministry of Public Administration and Local SelfGovernment, (2017). The Human Resource Management Framework Policy for Public Administration in the Republic of Serbia.

19. The Ministry of Public Administration and Local SelfGovernment, (2005). The Public Administration Reform Strategy in the Republic of Serbia and the Action Plan for the Public Administration Reform Strategy.

20. The Ministry of Public Administration and Local SelfGovernment The Public Administration Reform Strategy in the Republic of Serbia for 2014-2016, (2014) Official Gazette of RS 020-656/2014.

21. The Ministry of Public Administration and Local SelfGovernment, The Strategy for Professional Development of Civil Servants in the Republic of Serbia (Official Gazette of RS 56/2011, 51/2013).

22. The Republic of Serbia, (2015). Negotiation Group for Chapter 23, Action Plan for Chapter 23.

23. The Strategy for Development of Internal Financial Control in Public Sector in the Republic of Serbia for 2017-2020, 2017.

24. Uredba o uslovima, načinu i programu polaganja ispita općeg znanja $i$ stručnog ispita za kandidate za državnu službu u Federaciji BiH), "Official Gazette of FBiH" No. 67/06, 78/06, 63/08.

25. Вилијамс, С. (2015). Приручник за кориштење оквира компетенција у процесу запошљавања у државној служби у Босни и Херцеговини, Сарајево.

\section{Јачање административних капацитета кроз развој Оквира компетенција државних службеника}

Апстракт: Имајући у виду савремене тенденичје реформе јавне управе, европске стандарде развоја службеничког система и чињеницу да кониепт компетенција још увек није довољно 
познат стручној јавности, ичиљ рада је да ближе објасни значење u сврху компетенција у управљану људским ресурсима у државној управи. Аутор такође указује на актуелне трендове унапређена службеничког система кроз увођене Оквира компетенција и његово интегрисање у законодавство.

Стратешко опредељене представљено Оквиром политике управљања људским ресурсима у државној управи Републике Србије се првенствено односи на успостављане цуеловитог приступа управљању људским ресурсима заснованог на компетениијама - почев од планирања људских ресурса, одабира и запошљавања, увођења у посао, управљања учинком, развоја запослених, до изласка из организаџије. Усвајањем Оквира компетенција државних службеника у Републици Србији се подржава професионализачија државне управе и обезбеђује пуна примена принципа мериторности. Уграђен у свеобухватни систем управљањь људским ресурсима, Оквир компетенција ће утицати на побољиање радног учинка запослених и остваривање стратешких цииљева органа и организација. Идентификовање компетенција за делотворно обављање посла, јасно показује где треба усредсредити напоре, како у погледу личног развоја на садашьем радном месту, тако и у погледу развоја каријере државних службеника.

Аутор закључује да компетениије добијају на пуном значају интегрисањем у законодавство и пуном применом у свим функицјама управљања људским ресурсима. У ичљу увођења компетенција, неопходне су измене правног оквира - Закона о државним службеницима, других закона и подзаконских прописа и усвајање нових подзаконских прописа. Изменама правног оквира наставља се започета професионализачија државне управе и обезбеђује пуна примена принципа мериторности. Нови приступ управљању људским ресурсима тражи време и посвећеност, а првенствено едукацију запослених - развој потребних менацерских знаға и вештина.

Кључне речи: административна реформа, професионализација, јавни интерес, управљање људским ресурсима заснованим на компетенцијама. 